\title{
CONSUMER'S ATTITUDE AND WILLINGNESS TO PAY FOR ORGANIC RICE
}

\section{Qisthy Nur Fathia*), Rita Nurmalina**), and Megawati Simanjuntak ${ }^{* * * *}$}

\author{
*) School of Business, Bogor Agricultural University \\ Pajajaran Road, Bogor 16151 \\ ${ }^{* *}$ Departement of Agribusiness, Faculty of Economics and Management, Bogor Agricultural University \\ Jl. Kamper, Wing 4 Level 5 Campus of IPB Darmaga Bogor 16680 \\ ${ }^{* * *)}$ Department of Family and Consumer Sciences, Faculty of Human Ecology, Bogor Agricultural University
} IPB Darmaga Campus, Bogor 16680

\begin{abstract}
Government's support for Go Organic program provides a significant effect on the increasing organic land from only 71 thousand hectares in 2010 to 113 thousand hectares in 2014. This is caused by the shifting lifestyle of consumers who are more concerned about health. Rice as one of carbohydrate sources consumed by Indonesian people has an organic variant which is favored by many consumers. This study involved 100 households which were intentionally selected based on their convenience and readiness to be interviewed. This research was also conducted to analyze the comparison of consumer's attitudes on organic and nonorganic rice and to analyze consumer's willingness to pay (WTP) for organic rice. Fishbein and Contingent Valuation Method were used as an analytical tool to find out the consumers' attitudes and the maximum values that they are willing to pay. Consumers of non-organic rice had a more positive attitude on non-organic rice compared to organic rice with a WTP value of Rp 20,000 and the potential opportunity value that can be projected for organic rice in Bogor City is IDR291,788,621,400 per month.
\end{abstract}

Keywords: consumer's attitude, contingent valuation method, fishbein, organic rice, willingness to pay

\begin{abstract}
Abstrak: Dukungan pemerintah terhadap program Go Organik memberikan pengaruh nyata yaitu dengan adanya peningkatan lahan organik dari hanya sebesar 71 ribu hektar di tahun 2010 menjadi 113 ribu hektar di tahun 2014. Hal ini disebabkan oleh adanya pergeseran gaya hidup konsumen yang lebih peduli akan kesehatan. Beras sebagai salah satu sumber karbohidrat yang dikonsumsi oleh masyarakat Indonesia memiliki varian beras organik yang diminati oleh banyak konsumen. Penelitian ini melibatkan 100 rumah tangga yang dipilih secara sengaja berdasarkan kemudahan dan kesediaan responden untuk diwawancarai (convnience sampling) dengan tujuan menganalisis perbandingan sikap konsumen terhadap beras organik dan beras non organik serta menganalisis kesediaan konsumen beras non organik terhadap beras organik. Fishbein dan Metode Kontingen Valuasi digunakan sebagai alat analisis untuk mengetahui sikap dan nilai maksimum yang bersedia dibayarkan konsumen. Konsumen beras non organik memiliki sikap lebih positif terhadap beras non organik dibandingkan beras organik dengan nilai WTP sebesar Rp. 20.000 per kilogram dan nilai potensi peluang yang dapat diproyeksikan untuk beras organik di Kota Bogor adalah sebesar Rp291.788.621.400 per bulan.
\end{abstract}

Kata kunci: sikap konsumen, metode kontingen valuasi, fishbein, beras organik, kesediaan membayar,

\footnotetext{
${ }^{1}$ Corresponding author:

Email: qisthynurfathia@gmail.com
} 


\section{INTRODUCTION}

The demand for world organic food commodity continues to increase. Since 1997, the sale of organic commodity in the United States of America (USA) has increased from $\$ 3.6$ billion to $\$ 43.4$ billion in 2015 (OTA, 2016). The number of organic commodity producers in the world also kept increasing until it reached 2.3 billion in 2014 (Willer and Lernoud, 2016).

A study conducted by Jacob dan Jacob (2012) states that currently there is a shift of consumer's attitude and behavior to the environment. The government of Indonesia through the Ministry of Agriculture launched Go Organic Program in 2010 as a form of support for organic agriculture which is considered better for environment and health, as well as for an environmentally friendly agribusiness development. Go Organic Program turned out to have a positive impact on the development of organic commodity area in Indonesia, shown by the increasing vastness of organic commodity land from 71 thousand hectares in 2010 to 13 thousand hectares in 2014 (FAOSTAT, 2016). The increasing land's vastness was followed by consumers' thought which consider that green product has a higher quality compared to the product in general. Green product is also considered as one of the solutions to nurture the environment (Santoso dan Fitriyani, 2016). Most of the consumers, who have positive attitude on products that are environmentally friendly and care for health, do not consider the high price of organic products as a problem. Consumers even believe and are willing to pay more for organic product because it is considered necessary to pay a slightly more expensive price for an organic product compared to the conventional product (Ravensway, 1991). This statement is supported by the result of research carried out by Gil et al. (2000), Tanner and Kast 2003, and Laroche et al. (2001) which revealed that consumers are willing to pay more for organic products.

There are many consumers who are willing to buy organic products because they are interested in the products benefits. As explained by Gil et al. (2000) and Tanner and Kast (2003) in their respective research, consumers with strong positive attitude on organic foods feel that it is appropriate for organic foods to have a higher value compared to the non-organic foods. Women with higher education also have a better attitude to behavior of purchasing environmentally friendly products. They have more desire to consume organic products compared with men (Anvar and Venter, 2014). Another research conducted by ThØgersen et al.(2014) explained that consumer's attitude on the purchase of organic foods was strongly related to the belief about health, taste, and the environmental friendliness of the organic product. Consumers of organic products in China, Brazil, and USA revealed that their reason for purchasing organic products was the belief on health, taste, and environmental friendliness they obtained from the products. There are two variables which have a positive effect on the consumers' attitude to organic products, namely universality and products safety value.

Stoleru et al. (2012) on his study in Maldova explained that pice was one of the most important criteria according to consumers before they decided to buy organic rice. On another study, price was the most prioritized attribute by consumers in buying organic rice (Idaman et al. 2012). For example, the price of premium organic products in China was extremely high so that there were many consumers who were unable to afford it without ruling out other family essential needs (ThØgersen et al. 2014). Young et al. (2010), Wang (2007), Chen (2009), Sriwaranun et al. (2015) and Xie et al.(2015) agreed with Idaman et al.(2012) by stating that price became the most important attribute so that it became the main obstacle for consumers in buying organic products.

Generally, economic value is defined as the maximum value of goods and services a person willing to sacrifice to obtain other goods and services. This concept is called someone's willingness to pay (WTP) for goods and services produced by natural and environmental resources. In economic practice, WTP is utilized more often than willingness to accept (WTA) because WTA is not the right measurement tool for human-behaviorbased study (Fauzi, 2006).

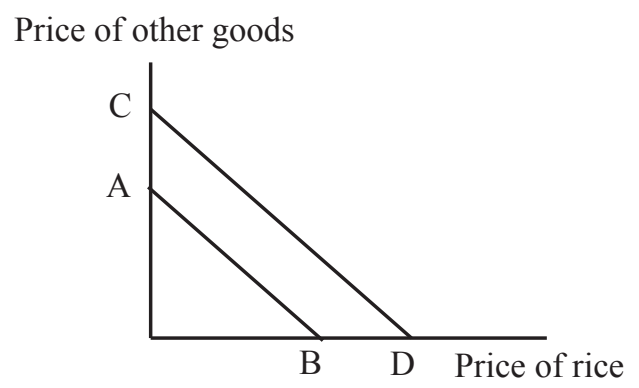

Figure 1. Budget line of organic and non-organic rice consumers 
WTP is closely related to consumption, both goods and services. The limit of consumption combinations which are affordable for the consumers according to their income is called budget line (Mankiw, 2012). It can be seen in Figure 1 that consumers choosing nonorganic rice $(\mathrm{AB})$ have a budget line that is lower than the consumers choosing organic rice $(\mathrm{CD})$. It is proven by several researches that consumers of organic products have a higher income than consumers of general products (Mutlu, 2007; Noviandi, 2012; Xie et al. 2015). The majority of organic products' consumers are people in the middle or upper-middle class economy (Mutlu 2007; Noviandi 2012). Because consumers of organic products have a higher income than the non-organic products' consumers, their consumption combinations are higher as well (CD budget line).

According to several existing researches, price always becomes one of the most considered attributes by the consumers before purchasing organic rice. It is proven by the result of research undertaken by ThØgersen et al.(2014) which stated that the high price of the product can prevent the purchase of organic products. Similar to ThØgersen et al.(2014) results, Rodriguez et al. (2008) concludes that consumers will increase their consumption of organic products if the price offered is more affordable.

Based on other studies on factors affecting consumers WTP, location of residence, education level, income range, and consumer perception about health benefits significantly affect consumers WTP toward organic products (Narine et al. 2013). In contrast to the previous research, Huang and Lee (2013) explain that there are only two factors that affect WTP of organic fresh milk, the logo of products and organic logos.

Consumers' willingness to pay for organic milk according to Amirnejad and Tonakbar (2015) research is significantly influenced by several factors. These are income, education, family health history, distance to shopping center, organic milk quality, and the price offered. Education in George (2013) study results was different from the research conducted by Amirnejad and Tonakbar (2015). Amirnejad and Tonakbar (2015) explain that education has a negative correlation to the consumers' willingness to buy organic products. On the other side, information attribute on research of George (2013) and Bienenfeld (2014) is organic product attribute which significantly affects the WTP of organic products.
Rice as one of staple food commodities which is consumed by most of Indonesian people has a higher price for the organic variant compared to the nonorganic one. The retail price of non-organic rice throughout 2016 ranged between IDR13,039 and Rp 13,319 per kilogram (BPS, 2016). If compared with the data owned by BPS (2016), the researcher's field survey result found out that organic rice price in the market ranged between IDR16,000 and IDR40,000 per kilogram. This price variation is caused by the different type, quality, and selling location. Most of Indonesian consumers still consider price as the primary hindrance in buying organic rice. The price of organic rice which is always higher than the price of non-organic rice makes this commodity interesting to observe.

The objectives of this research were to analyze consumer's attitude to organic rice, to analyze consumer's willingness to pay (WTP) for organic rice, and to analyze factors influencing consumer's WTP for organic rice.

This research was conducted on 100 households in North Bogor Sub-district, Bogor City. The requirements of respondent consist of non-organic rice consumers who understand the relevant attitude to organic rice, namely price, taste, aroma, package, brand, information on package, efficacies/benefits, the availability of rice in the market, type of rice, rice buying place, and rice promotion. This research focuses on analyzing consumer's attitude and WTP to organic rice, as well as factors influencing consumer's WTP to organic rice.

\section{METHODS}

The data and information in this research was the primary type which was collected using structured questionnaire instrument. The interviewed respondents were selected purposively based on convenience on the basis of the respondents' willingness to be interviewed. The criteria of the respondents were that they are nonorganic rice consumers, routinely purchase non-organic rice, and understand the attributes of attitude, namely price, taste, aroma, package, brand, information on the package, benefits, the availability of rice in the market, types of rice, rice buying place, and rice promotion. The samples taken which amounted to 100 households using convenience method which had met the minimal sampling requirement for correlation research, namely 30 people (Gay and Diehl, 1992; Fraenkel and Wallen, 
1993) and amounted to five times the variables, namely 45 (Malhotra, 1993) with the aim to minimize the error and anticipate the presence of respondents that were unwilling to be interviewed.

This research was carried out in Bogor City, specifically in Kelurahan Tegal Gundil, North Bogor Sub-district, for three months, starting from November 2015 to January 2016. Research location was selected purposively with certain criteria, namely having a uniformity of economy level (middle class economy) and dwelling place environment, as well as convenience and the people's willingness to be interviewed.

This research measures attitude through 11 attribute of variables which proceed by fishbein multiattribute attitude model to know how non-organic rice consumers attitude to organic rice. Description of these attribute explained on Tabel 1.

This research also measured the Willingness to Pay (WTP) by using contingent valuation method and logistic regression to know the number of WTP, potential aggregate value of organic rice in Bogor City, and factors influencing consumers to buy organic rice. Dependent variable in logistic reggression consist of gender, knowledge, education, work status, the status of "had or had not bought" organic rice, age, income, and consumer's attitude to organic rice with WTP as its independent variable.
The data collected were based on the questionnairefilling obtained from intensive interview with the respondents covering the respondents' attitude and willingness to pay for organic rice. Other data were acquired from field survey result in several supermarkets and stores in Bogor City which sell organic rice to find out the actual price of various types of organic rice per kilogram. In this study, researcher used fishbein multiattribute model analysis and contingent valuation method analysis as explained below.

\section{Fishbein Multiattribute Attitude Model Analysis}

Fishbein multiattribute attitude model describes that consumer's attitude to a product or brand is determined by two things, namely the belief on an attribute (component $\mathrm{Bi}$ ) and the evaluation of the product's attribute (component Ei). This model is described by the following formula.

$$
\mathrm{Ao}=\sum_{i=1}^{n} B i E i
$$

Description: Ao (Attitude to an object); $\mathrm{Bi}$ (The strength of belief that the object has an i attribute); Ei (Evaluation on $\mathrm{i}$ attribute); $\mathrm{N}$ (The number of attribute owned by the object).

Table 1. Description of attitude attribute

\begin{tabular}{ll}
\hline \multicolumn{1}{c}{ Attribute } & \multicolumn{1}{c}{ Description of attribute } \\
Price & Price of organic/non-organic rice \\
Product & \\
Taste & Taste of oranic/non-organic rice \\
Flavour & Smell/Flavour of organic/non-organic rice \\
Packaging & Design and shape of organic/non-organic rice \\
Brand & Name of brand of organic/non-organic rice \\
Product information on packaging & Information on organic/non-organic rice packaging about nutrition facts, etc. \\
Products benefit & Organic/non-organig rice are prooved gives benefit for consumer/buyer \\
Product availability in market & Do organic/non-organic rice product has their availability in market or not \\
Variety & Rice variety sold in Indonesia, like mentik wangi, pandan wangi, etc \\
Place and Promotion & \\
Place of selling point & Where consumer bought organic/non-organic rice \\
Product promotion & Promotion from advertising, discount, etc \\
\hline
\end{tabular}


There are several steps to find out attitude score from fishbein multiattribute attitude model. The first step that must be done is to get strength of belief and evaluation on attribute score based on some attribute of rice consumer 's attitude that has been determined. Strength of belief (Bi) and attitude evaluation (Ei) are assessed using Likert scale from one to five, with one as the lowest score and five as the highestt. Furthermore, score of strength of belief and evaluation were multiplied to get the score of fishbein attitude model (Ao) which can be interpreted later as consumer's attitude of organic and non-organic rice.

\section{Contingent Valuation Method Analysis}

A survey approach on the estimation of benefit is usually known as contingent valuation method (CVM) because the result depends on the market hypothesis design. CVM has these following five operational implementation stages (Fauzi, 2006): creating hypothetical market, setting bids, calculating average WTP, estimating demand, aggregating data.

The approach used in this research was Payment Card Method, with which the researchers offered several prices to the respondents which later became the maximum value that a consumer was willing to pay for organic rice per kilogram. To analyze factors influencing WTP for organic rice, the basic calculation formula with logistic regression equation used was as follows.

$$
\begin{aligned}
\mathrm{WTP}_{\mathrm{ij}}= & \beta_{0}+\beta_{1}{ }^{*} \text { Gen }+\beta_{2}{ }^{*} \text { Know }+\beta_{3}{ }^{*} \text { EduDummy }+ \\
& \beta_{4} \text { WorkDummy }+\beta_{5}{ }^{*} \text { EverBuyOr }+\beta_{5}{ }^{*} \text { AttOr } 2 \\
& +\beta_{6}{ }^{*} \text { Age } 2+\beta_{7}{ }^{*} \text { IncDummy }+\varepsilon
\end{aligned}
$$

Description: $\mathrm{WTP}_{\mathrm{ij}}$ (the willingness of respondenti to buy organic rice $(0=$ unwilling; $1=$ willing $)$ ); DummyGen (gender $(0=$ female; $1=$ male $)$ ); Know (respondent's knowledge about organic); DummyEdu (respondent's education $(0=<$ bachelor degree; $1=>$ bachelor degree)); DummyWork (respondent's work status $(0=$ not working; $1=$ working $))$; Dummy EverBuyOr (respondent's status of "had or had not bought" organic rice $(0=$ had bought; $1=$ had not bought)); AttOr2 (consumer attitude on organic rice); DummyAge2 (respondent's age $(0=<41$ years old; $1=>41$ years old)); DummyInc (respondent's income $(0=<\mathrm{Rp} 10$ million; $1=>\operatorname{Rp} 10$ million $)) ; \beta_{\mathrm{i}}$ (regression coefficient).
Logistic regression equation uses a significance level of $10 \%(\alpha=0.10)$ and $15 \%(\alpha=0.15)$ and aims to identify factors influencing WTP or whether consumers were willing or unwilling to replace the consumption of nonorganic rice with organic rice. Researcher use $10 \%$ and $15 \%$ level of significance to increase the possibility of significant attribute which influencing consumers WTP for organic rice. WTP is made as the dependent variable with the independent variables comprising gender, knowledge, education, work status, the status of "had or had not bought" organic rice, age, income, and consumer attitude on organic rice.

The operational framework of this research can be seen in Figure 2 as it pictures the series of methods used to identify consumer's attitude and willingness to pay for organic rice. From the framework above, it can be concluded that at this time when the trend of healthy living is increasing, price of organic rice is still expensive for most consumers. Therefore, the researcher wants to know how the tendency of consumer attitude to organic rice is and on what price consumers are willing to pay for organic rice per kilogram. Results of the study through some literature that became assumption in this study are consumers have a positive attitude to organic products and provide higher value for organic products. Factors that affect consumers' willingness to buy organic products are education, income, price, attitude, age, and information towards organic products

\section{RESULTS}

\section{Consumer Attitude on Organic and Non-Organic Rice}

Consumer attitude, in this research, was measured using Fishbein multiattribute attitude model which was obtained from the result of multiplication between the value of consumer belief and the value of attribute evaluation. The five mostimportant attributes considered by the consumers (highest attribute evaluation values) consisted of the availability of rice in the market (4.18), information on the package (4.15), benefits (4.03), taste (4.03), and price (3.925).

The overall values of consumer belief on non-organic rice were positive ranging between 3.12 and 4.69. The highest value was owned by the attribute of availability of rice in the market (4.69) while the attribute of information on the package (3.2) was the attribute with 
the lowest value of belief. On the other hand, in terms of organic rice, the attribute with the highest value of belief was the attribute of benefits of organic rice with the score of 4.26 , while the lowest value was owned by the price attribute with the value of 2.4. The scores show that consumer's belief on the benefits of organic rice was really high; however, the price offered was still quite expensive so that the value of belief for the price attribute was at the bottom.

There was a difference of level of belief between attributes of organic rice and non-organic rice. In terms of non-organic rice, almost overall attributes had a high value of belief. Those attributes were price, taste, aroma, brand, availability, varieties, rice selling place, and promotion. Meanwhile, in terms of organic rice, the attributes which had a high value of belief were benefits, product information, and package (Figure 3). Consumers felt that non-organic rice was superior in those attributes, namely had a better taste and aroma, more varied types of rice offered, a more accessible selling place, and more promotion through advertisements on various media. However, in other three attributes, namely benefits, information on the package, and package, consumers believed that organic rice had a far higher benefits, a more complete information on the package, and a better package compared to non-organic rice. The result of Fishbein multiattribute attitude analysis is shown in Table 2.

Consumers who became the respondents of this research were non-organic rice consumers. That condition made consumer's attitude more positive on non-organic rice compared to their attitude on organic rice with the value of 158.60 for non-organic rice and 137.70 for organic rice. It can be seen from Table 2 that consumers preferred non-organic rice to organic rice. The belief and attitude of consumers who consumed organic rice on daily basis prefer organic rice to nonorganic rice. Therefore, it can be summed up that habit can determine the consumer's preferable attitude to a product.

\section{People's concern on health is rising}

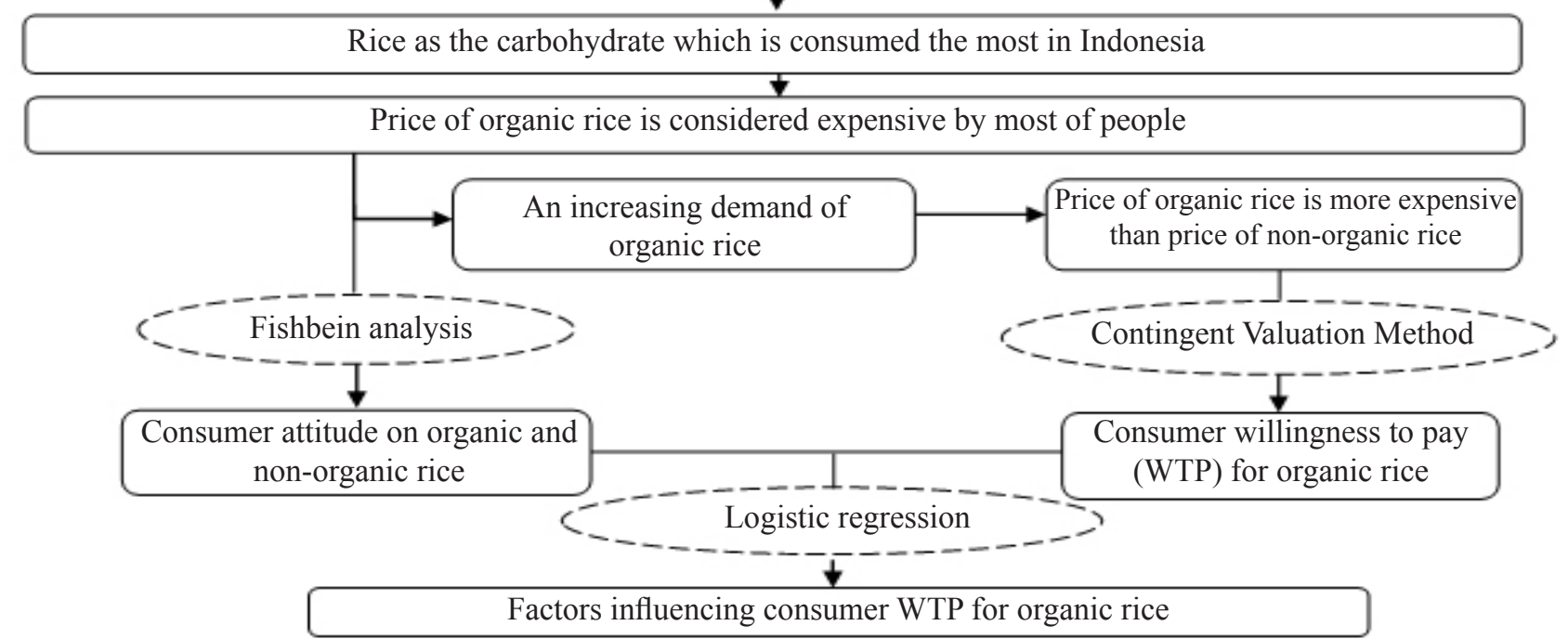

Figure 1. Research framework
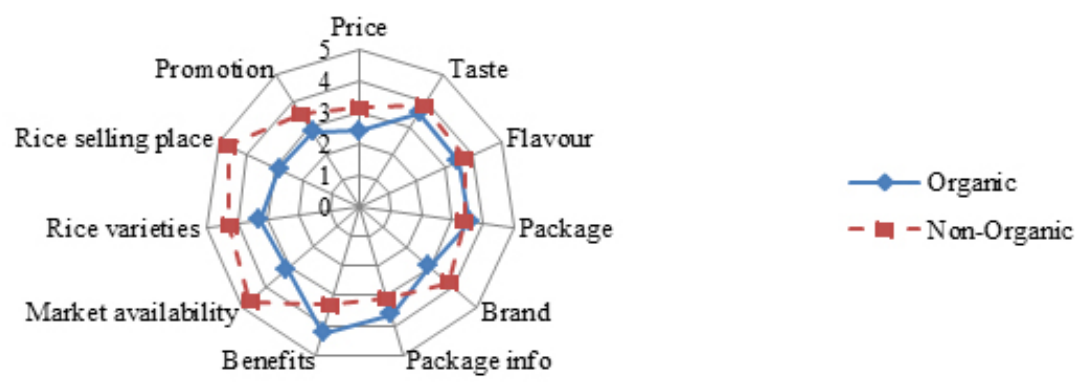

Figure 3. The Difference of level of Belief (Bi) on the attributes of organic and non-organic rice 
Table 2. The result of Fishbein multiattribute attitude analysis for organic and non-organic rice

\begin{tabular}{|c|c|c|c|c|c|}
\hline \multirow{2}{*}{ Organic attributes } & \multirow{2}{*}{$\mathrm{Ei}$} & \multicolumn{2}{|c|}{ Organic } & \multicolumn{2}{|c|}{ Non-organic } \\
\hline & & $\mathrm{Bi}$ & $\mathrm{Ei} \mathrm{Bi}$ & $\mathrm{Bi}$ & $\mathrm{Ei} \mathrm{Bi}$ \\
\hline Price & 3.925 & 2.4 & 9.42 & 3.15 & 12.36 \\
\hline Taste & 3.97 & 3.55 & 14.09 & 3.81 & 15.13 \\
\hline Flavour & 3.81 & 3.46 & 13.18 & 3.71 & 14.14 \\
\hline Package & 3.44 & 3.55 & 12.21 & 3.39 & 11.66 \\
\hline Brand & 3.31 & 2.93 & 9.70 & 3.76 & 12.45 \\
\hline Information on the package & 4.15 & 3.62 & 15.02 & 3.12 & 12.95 \\
\hline Benefits & 4.03 & 4.26 & 17.17 & 3.31 & 13.34 \\
\hline Availability of rice in the market & 4.18 & 3.12 & 13.04 & 4.69 & 19.60 \\
\hline Rice varieties & 3.78 & 3.28 & 12.40 & 4.27 & 16.14 \\
\hline Rice selling place & 3.64 & 2.86 & 10.41 & 4.68 & 17.04 \\
\hline Promotion & 3.92 & 2.82 & 11.05 & 3.52 & 13.80 \\
\hline Total & & & 137.70 & & 158.60 \\
\hline
\end{tabular}

\section{Analysis of Consumer's Willingness to Pay for Organic Rice}

Of the 100 respondents, most of them (76\%) were willing to switch from non-organic rice to organic rice as a form of quality enhancement with health factor as the reason. There were $24 \%$ of respondents who were unwilling to switch their non-organic rice consumption to organic rice due to two reasons, namely consumers currently had been satisfied with the non-organic rice they consumed and they felt that the price of organic rice sold in the market was too expensive.

Price of organic products is one of the variables that are considered important by consumers. It is also reflected in this research that most of the consumers who were unwilling to switch to organic rice stated that the price offered in the market was too high. Because the price in the market was considered high, the analysis of consumer's willingness to pay for organic rice was conducted. The analysis used Contingent Valuation Method (CVM) which comprises the following five stages.

\section{Hypothetical Market}

Before being interviewed, the respondents were explained beforehand that organic rice is a product that is healthy, natural, and produced in an environmentally friendly manner.

\section{Value of Payment Cards}

The value that a consumer is willing to pay for organic rice was selected by consumer based on payment cards method, in which there were five choices of price offered, namely IDR16,000, IDR20,800, IDR25,600, IDR32,000, and IDR40,000 per kilogram. Price was determined based on a field survey conducted in several organic rice selling places, such as exhibition, modern market, and special stores that sell organic rice. More than half of consumers $(59 \%)$ chose the lowest price in the market, namely IDR16,000 per kilogram of organic rice.

\section{Average value of WTP}

Consumers' average value on organic rice based on the calculation result as shown in Table 3 was IDR20,000 per kilogram.This value is IDR4,000 higher than the lowest price of organic rice sold in the market.

\section{Payment Card Curve}

Two variables are needed to create a bid curve, namely number of respondents and consumer WTP price for organic rice. Figure 4 portrays the relation between number of respondents and consumer WTP value for organic rice. The higher the WTP price offered, the lower the number of respondents who were willing to buy organic rice at that price. 
Table 3. WTP price distribution for organic rice

\begin{tabular}{cccc}
\hline WTP value (Rp) & Number of respondents (people) & Mean WTP (IDR/person) & Aggregate WTP/month (IDR) \\
\hline 16,000 & 59 & 9,440 & \\
20,800 & 22 & 4,576 & \\
25,600 & 9 & 2,304 & $291,788,621,400$ \\
32,000 & 4 & 1,280 & \\
40,000 & 6 & 2,400 & \\
\hline Total & 100 & 2,000 & \\
\hline
\end{tabular}

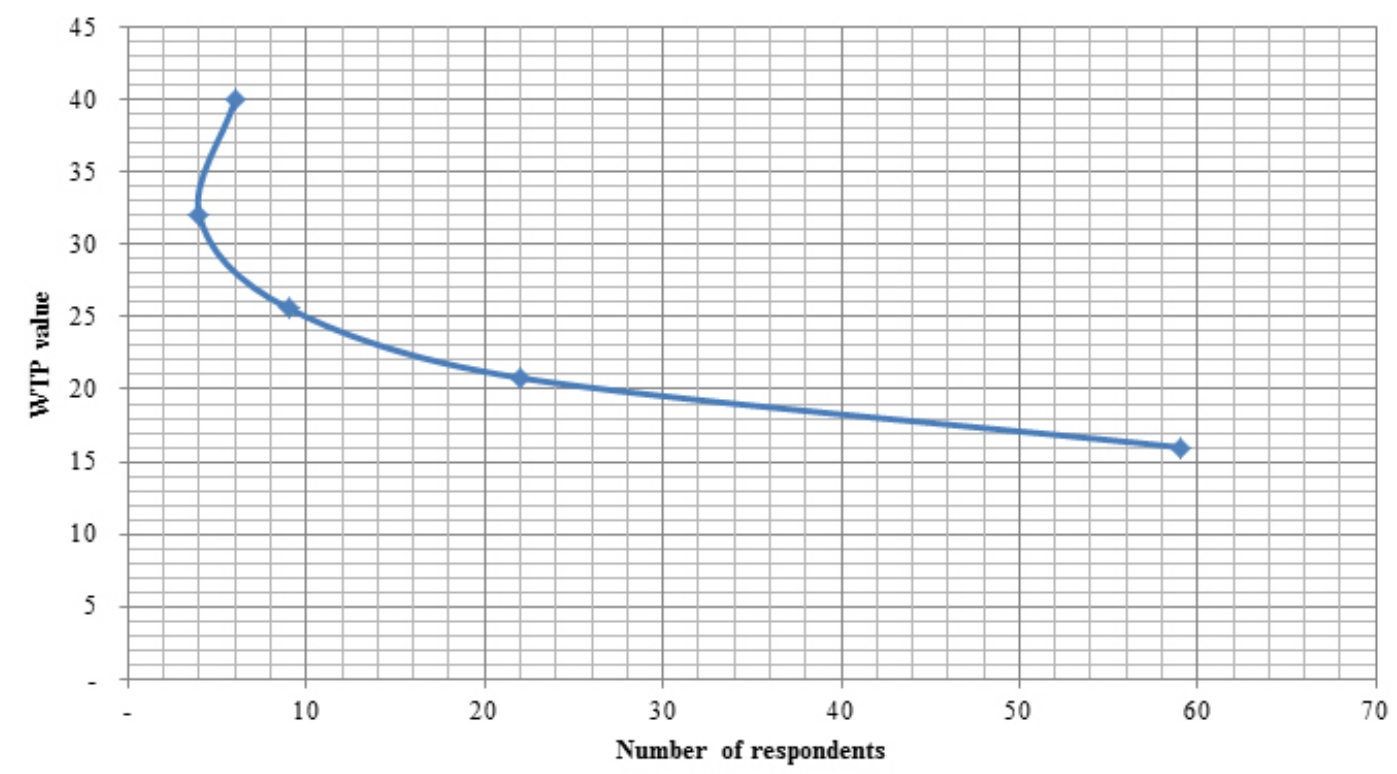

Figure 4. Estimation of demand based on respondents of organic rice

\section{Aggregate Data}

Aggregating the data in CVM method is conducted by multiplying average value of WTP and number of households within the middle and upper-middle social economic levels in Bogor City. The multiplication generated the aggregate value of organic rice of IDR291,788,621,400 per month as the potential opportunity value that can be projected for organic rice producers or sellers in Bogor City (Table 3).

\section{Factors Influencing Willingness to Pay for Organic Rice}

Factors influencing consumer WTP for organic rice was analyzed using logistic regression, in which the dependent variable used was consumers are willing (1) or unwilling (0) to switch from non-organic rice to organic rice. Independent variables that were expected to influence the dependent variable (WTP) were gender (X1), knowledge (X2), education (X3), work status (X4), the status of had bought organic rice (X5), attitude (X6), age (X7), and income (X8). The analysis result is presented in Table 4.
WTP in this research came from logistic regression using entry method, in which all variables were put into the model simultaneously. In terms of model feasibility test, it can be seen in Table 5 that the significance value of the model was 0.08 and it was less than the significance level used, which was $15 \%$. It means that the model could explain the variations of occurrence of WTP for organic rice.

The percentage of model variations can be explained by $\mathrm{R}$ square value as revealed in Table 5 , which was 0.191 or $19.1 \%$. The value indicates that independent variables were able to explain the occurrence of WTP for organic price by $19.1 \%$. Based on that regression result, the equation model of WTP for organic rice can be arranged as follows.

$$
\begin{aligned}
\text { WTP }= & -8.92+0.5 \mathrm{X} 1+0.028 \mathrm{X} 2+1.212 \mathrm{X} 3-0.560 \\
& \mathrm{X} 4+0.636 \mathrm{X} 5+0.07 \mathrm{X} 6+0.61 \mathrm{X} 7+0.779 \\
& \text { X8 }
\end{aligned}
$$


Table 4. Result of logistic regression analysis on WTP value for organic rice

\begin{tabular}{lccc}
\hline \multicolumn{1}{c}{ Variables } & $\mathrm{B}$ & Sig & Exp(B) \\
\hline Gender & 0.500 & .469 & 1.65 \\
Knowledge & $\left.0.028^{* *}\right)$ & .102 & 1.03 \\
Education & 1.212 & .283 & 3.36 \\
Work status & -0.560 & .393 & 0.57 \\
Status of had bought organic rice & 0.636 & .297 & 1.89 \\
Attitude & 0.007 & .394 & 1.01 \\
Age & $\left.0.061^{*}\right)$ & .055 & 1.06 \\
Income & $\left.0.779^{* *}\right)$ & .141 & 2.18 \\
Constants & -8.920 & .001 & 0 \\
\hline
\end{tabular}

*)level of significance $10 \%$; **)level of significance $15 \%$

Table 5. Coefficient value of logistic regression model

\begin{tabular}{|c|c|c|}
\hline Coefficients of Model & Significance & R Square \\
\hline Step & 0.08 & \\
\hline Block & 0.08 & 0.191 \\
\hline Model & 0.08 & \\
\hline
\end{tabular}

Based on the above result of logistic regression analysis, it can be explained that there were three independent variables which had a significant influence on consumer WTP for organic rice. Those variables were age (sig. model $0.055<0.10$ ), knowledge (sig. model $0.102<0.15$ ), and income (sig. model $0.141<0.15$ ).

\section{Managerial Implications}

As one of the significant variables to consumers' willingness to pay for organic rice, the consumer's limited knowledge about organic products can affect them to buy organic products (Xie et al. 2014). Knowledge and information also caused consumers to change their tendency toward organic product (Kalashami et al. 2012). Therefore, producers can educate consumers through organic rice packaging that describes the benefits of organic rice as a form of raising awareness of organic rice products.

With reference to the results of the study, increasing age makes consumers more concerned about health, thus increasing their chances to buy organic rice, which in turn enables the producers to specialize in the type of education based on age segmentation. Education of organic rice that gives more attention to health is devoted to age segmentation for over 40 years, while for below 40 years producers can make a combination of health and environmental issues as a driver to make consumer interested to buy organic rice. Education can also be done through various media, such as mass media or online media as a form of promotion.

Consumers of organic products majority came from middle and upper economic levels. This is proven through the research which shows that income significantly affects the consumers' willingness to pay for organic rice. It can be concluded that the right target as an organic rice consumer is a family of middle and upper classes. Ratio opportunity of the study also supports this, because if consumers have revenues above IDR10 million it can increase the chances of consumers to pay for organic rice by 2.18 times.

Consumers' interest to organic rice can be seen from most trusted attributes by consumers. In this study, most trusted attribute of organic rice consists of benefits in organic rice, information on packaging, and organic rice packaging. Manufacturers can take advantage of this consumer's attitude as an opportunity to market organic rice. For example, manufacturers can design packaging with a very attractive look, complemented with benefits of organic rice for health and environment, as well as complete information on nutrition information.

Consumers considered that the availability of organic rice is very limited because it is hard to find. Organic rice is only available in certain places, such 
as supermarkets or specialty organic stores. From the findings, producers are advised to pay more attention to the distribution pattern of organic rice so that consumers can get organic rice products more easily.

As an organic product, organic rice has a higher price than non-organic rice. High prices often become a barrier for consumers to buy organic rice. The existence of promotional prices at certain times can be used as an alternative form of promotion to encourage consumers to buy organic rice.

\section{CONCLUSIONS AND RECOMMENDATION}

\section{Conclusions}

Consumers had a positive attitude on organic rice with the total score of 137.70 and 158.60 for non-organic rice. It is because the consumers consumed nonorganic rice so that it influenced their attitude on both organic and non-organic rice. The value of consumer WTP for organic rice amounted to IDR20,000 per kilogram and only $76 \%$ of consumers were willing to switch their consumption from non-organic rice to organic rice. The aggregate value of WTP amounted to IDR291,788,621,400 per month as a depiction of potential opportunity value of organic rice market in Bogor City. Of the eight independent variables, there were three independent variables which had a significant impact on consumer's willingness to switch to and consume organic rice. Those variables were age, knowledge, and income with $10 \%$ and $15 \%$ of level of significance.

\section{Recommendations}

There were several recommendations that can be provided for rice consumers, especially non-organic rice consumers who are interested to try consuming organic rice. Consumers are expected to enhance the information regarding organic agriculture particularly organic rice before purchasing. WTP price generated in this research can also be made as a recommendation for consumers who are willing to buy organic rice, certainly with product quality consideration. If consumers have had adequate information and knowledge about organic rice, consumers will be more selective and consider a high price as a form of health and environmental investment for the future.
Improving consumers' information and knowledge about organic rice can be done through cooperation between producers and some institutions that are specifically engaged in organic field. Producers can also add organic labels as well and shows some kind of benefits obtained by purchasing and consuming organic products on organic rice packaging. The presence of public service advertisements on certified organic product logos can also help consumers to be more acquainted with and conscientious of choosing and buying organic products, especially organic rice.

\section{REFERENCES}

Anvar M, Venter M. 2014. Attitudes and purchase behaviour of green products among generation $\mathrm{y}$ consumers in South Africa. Mediterranean Journal of Social Sciences 5(21):183-194. https://doi.org/10.5901/mjss.2014.v5n21p183.

Amirnejad H, Tonakbar P. 2015. The willingness to pay organic milk by consumers in Tehran. Journal of Agricultural Science and Technology. 17(2015):1685-1694.

Bienenfeld JM. 2014. Consumer willingness to pay for organic, environmental, and country of origin attributes of food products. [dissertation]. Columbus: The Ohio State University.

[BPS] Badan Pusat Statistik. 2016. Monthly Report of Social Economic Data (in Indonesian). Jakarta: BPS.

Chen MF. 2009. Attitude toward organic foods among taiwaneese as related to health consciousness, environmental attitudes, and the mediating effects of a healthy lifestyle. British Food Journal 111(2): 165-178. https://doi. org/10.1108/00070700910931986.

[FAOSTAT]FoodAgriculture Organization ofthe United Nation Statistic Division. 2015. Agricultural Organic Area. http://faostat3.fao.org/search/ organic\%20land/E.[20 January 2015]

Fauzi A. 2006. Environmental and Natural Resources Economics: Theory and Application (in Indonesian). Jakarta: PT Gramedia Pustaka Utama.

Fraenkel J, Wallen N. 1993. How to Design and Evaluate Research In Education. Second Edition. New York: McGraw-Hill Inc.

George S. 2010. Wllingness to pay for locally grown and organically produced fruits and vegetables 
in Dominica [thesis]. Clemson: The Graduate School of Clemson University.

Gay LR, Diehl PL. 1992. Research Methods for Business and Management. New York: MacMillan Publishing Company.

Gil JM, Gracia A, Sanchez M. 2000. Market segmentation and willingness to pay organic product in Spain. International Food and Agribusiness Management Review 3(2):207-226. https://doi.org/10.1016/S10967508(01)00040-4.

Huang C, Lee C. 2013. Consumer willingness to pay for organic fresh milk in Taiwan. China Agricultural Economic Review 6(2): 198-211.https://doi. org/10.1108/CAER-04-2012-0033.

Idaman N, Yuliati LN, Retnaningsih. 2012. Consumer attitude on organic rice (in Indonesian). Jurnal Manajemen dan Agribisnis. 9(2): 117-126.

Jacob C, Jacob J. 2012. Green marketing: a study of consumer attiude towards environment friendly. Asian Social Science 8(12):117-126.

Kalashami M, Heydari M, Kazaerani H. 2012. Investigasting consumer's WTP for organic chicken in Iran. International Journal of Agricultural Management and Development 2(4): 235-241.

Laroche M, Bergeron J, Barbaru-Forleo G. 2001. Targeting consumers who are willing to pay more for environmentally friendly products. Journal of Consumer Marketing 18(6): 503-520. https:// doi.org/10.1108/EUM0000000006155.

Malhotra NK. 1993. Marketing Research an Applied Orientation. Second Edition. Upper Saddle River: Prentice Hall International Inc.

Mankiw NG. 2012. Principle of Economics. Stamford: Cengage Learning.

Mutlu N. 2007. Consumer attitude and behaviour towards organic food: cross cultural study of Turkey and Germany. [Thesis]. Stuttgart: Universitat Hohenheim.

Narine L, Ganpat W, Seepersad G. 2015. Demand for organic produce: trinidian consumers willingness to pay for organic tomatoes. Journal of Agribusiness in Developing and Emerging Economies 5(1): 76-91. https://doi.org/10.1108/ JADEE-04-2013-0015.

Noviandi A. 2012. Analysis of behavior of rice consumers and implications on marketing strategy (in Indonesian) [thesis]. Bogor: IPB.
[OTA] Organic Trade Association. 2016. Organic Market Analysis. https://www.ota.com/ resources/market-analysis [16 Maret 2016].

Rodriguez E, Locaze V, Lupin B. 2008. Contingent valuation of willingness to pay for organic food in Argentina. In 12th Congress of The European Association of Agricultural Economist (EAAE); 2008 Agustus 26-29; Ghent, Belgium. Ghent (BE).

Santoso I, Fitriyani R. 2016. Green packaging, green product, consumer perception, and purchasing interest (in Indonesian). Jurnal Ilmu Keluarga dan Konsumen 9(2):147-158. https://doi. org/10.24156/jikk.2016.9.2.147.

Sriwaranun Y, Gan C, Lee M, Cohen D. 2015. Consumers willingness to pay for organic products in Thailand. International Journal of Social Economics 42(5): 480-510. https://doi. org/10.1108/IJSE-09-2013-0204.

Stoleru V, Munteanu N, Jiteareanu AF. 2012. Consumer behaviour from moldova area towards organic food. Journal Lucrări Ştiinţifice Seria Agronomie 55(2): 283-287.

Tanner C, Kast SW. 2003. Promoting sustainable consumption: determinants of green purchases by Swiss consumers. Journal Psychology and Marketing 20(10): 883-902. https://doi. org/10.1002/mar.10101.

ThӨgersen J, Barcelos M, Perin M, Zhou Y. 2015. Consumers buying motives and attitudes towards organic food in two emerging markets: China and Brazil. International Marketing Review 32(3/4): 389-413. https://doi.org/10.1108/IMR-06-20130123.

Wang P, Pei C. 2007. Consumer behavior and willingness to pay for organic product. [thesis]. San Jose: San Jose State University.

Willer H, Lernoud J. 2016. Organic Agriculture Worldwide 2016: Current Statistics. Frick: Research Institute of Organic Agriculture (FiBL).

Xie B, Wang L, Yang H, Wang Y, Zhang M. 2015. Consumer perception and attitudes of organic food products in eastern China. British Food Journal 117(3): 1105-1121. https://doi. org/10.1108/BFJ-09-2013-0255.

Young W, Hwang K, McDonald S, Oates CJ. 2010. Sustainable consumption: green consumer behavior when purchasing products. Journal of Sustainable Development 18(1): 20-31. 